\title{
The ACCIDENTAL Consistency: Extracting a Coherent Principle From The JURISPRUDENCE SURROUNDING Solicitor Client Privilege BetWeen The Police AND THE CROWN
}

\author{
MARC S. GORBET
}

The development of a clear and consistent approach to solicitor client privilege between the police and the Crown has met with significant difficulty. The author argues, however, that despite a lack of apparent clarity in both jurisprudence and legislation, a closer examination reveals that a type of "accidental consistency" has developed, whereby the police can maintain privileged communication with Crown counsel, provided they remain at arms length from actual prosecution in an advisory capacity only. The author then calls for this "accidental consistency. "to become more clearly codified in future jurisprudence and argues that the optimum model to ensure the maintenance of privilege would be the use of independent, in-house counsel by the police.
Le développement d'une démarche claire et cohérente à l'égard du secret professionnel liant l'avocat à son client qui existe entre la police et la Couronne a rencontré de considérables difficultés. L'auteur prétend cependant que malgré le manque apparent de clarté dans la jurisprudence et la législation, un examen plus approfondi révèle qu'un genre de "cohérence accidentelle "s'est développée, en ce sens que la police conserve des communications privilégiées avec l'avocat de la Couronne dans la mesure où elle demeure autonome de la poursuite et agit seulement à titre consultatif. L'auteur suggère ensuite que cette "cohérence accidentelle " soit codifiéc plus clairement dans les futures jurisprudences et fait remarquer que le modèle optimal de maintien de ce privilège serait le recours, par la police, à un avocat indépendant interne.

TABLE OF CONTENTS

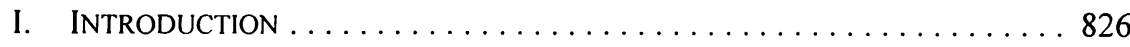

II. Solicitor Client Privilege . . . . . . . . . . . . . . . . . . . . . . 827

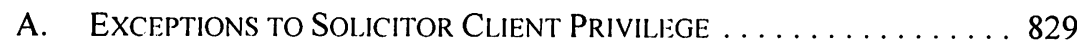

III. THE CONFUSION IN THE JURISPRUDENCE $\ldots \ldots \ldots \ldots \ldots \ldots \ldots \ldots . \ldots \ldots 1$

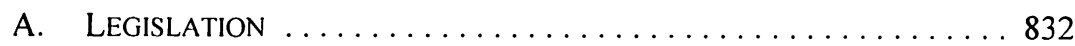

B. CATEGORIZING THE JURISPRUDENCE:

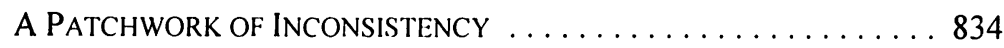

IV. PRactical PROBlems From the INCOHERENT

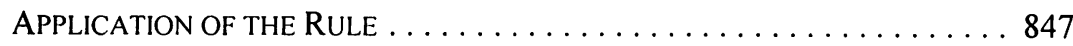

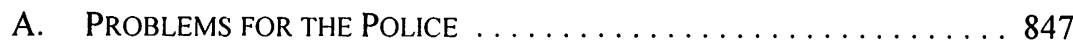

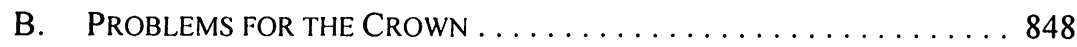

V. CONCLUSION: THE OPTIMUM MOdEL FOR THE POLICE IS

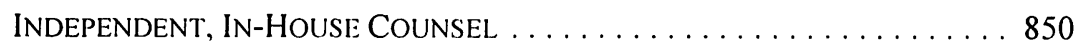

Third year law student, Dalhousie Law School. The author would like to acknowledge Professor S.

Coughlan for his input, direction, and guidance during the course of researching and writing this article. 
"[T]he suggestion that a solicitor-and-client relationship exists between a police officer and Crown counsel is untenable."

"[S]ome Courts have assumed a solicitor-client relationship existed between a Crown prosecutor and an investigator."

"It is of great importance, therefore, that the RCMP be able to obtain professional legal advice in connection with criminal investigations without the chilling effect of potential disclosure of their confidences in subsequent proceedings."

The jurisprudence surrounding solicitor client privilege in the police/Crown context appears to present a patchwork of inconsistency and confusion. The difficulty for the courts seems to stem from the special status of both the Crown and the police and from how their relationship fits within the traditional rules surrounding privilege. Sometimes, the courts find that solicitor client privilege exists, sometimes the privilege is just assumed to exist and, when either found or assumed, it is almost always waived. Other times the courts have held that such a privilege could never exist. The confusion is created as a result of the inconsistent reasoning used to determine the existence of any privilege. However, a closer examination of that reasoning reveals a pattern of consistency. Although never formally articulated, this accidental consistency does provide a coherent model for the police to obtain privileged legal advice. The subtle principle stands for the idea that the police can maintain a privileged communication with a Crown counsel, provided the Crown counsel is at arms length from the actual prosecution in an advisory capacity.

Although this proposition does resolve the incoherence in the case law surrounding the issue of privilege between the Crown and police, it does not provide the optimal situation. By naturally extending the reasoning from the jurisprudence on this issue, the creation of independent, in-house advisor positions within the police community would provide the best practice for the police and for maintaining the integrity of the administration of justice. The police's use of independent, in-house counsel would not only adhere to the principles articulated in the jurisprudence, but would afford the police privileged legal advice that serves their unique situation and accurately reflects the use of solicitor client privilege in the traditional sense.

\section{INTRODUCTION}

This article is broken down into four parts. The first will briefly look at solicitor client privilege and its exceptions in the traditional sense. Highlighting the core concepts will be essential to understanding the difficulties in applying solicitor client privilege outside of the traditional sphere. The second part will look at the jurisprudence on solicitor client privilege between the Crown and police. In looking at the inconsistencies in the case law from the perspective of the Crown, it will be seen that there is an unacknowledged consistency running

R. v. Girouard (1982), 68 C.C.C. (2d) 261 at 272 (B.C.S.C).

R. v. Regan [Solicitor Client Privilege Application],[1996] N.S.J. No. 624 at para. 18 (Prov. Ct.) (QL)

[Regan Application].

R. v. Campbell, [1999] I S.C.R. 565 at para. 49 [Campbell]. 
throughout the jurisprudence. The third part will demonstrate some of the practical problems for the police and the Crown that arise as a result of this unarticulated concept. The fourth will present an optimum model for access to privileged legal advise for the police. By using in-house, independent counsel the police will not only be adhering to the jurisprudence on this issue, but will have access to legal advice that will be protected by privilege.

\section{Solicitor Client Privilege}

One of the rare "class" privileges, solicitor client privilege provides that certain communications between a client and their solicitor are not subject to be disclosed. Although these class privileges are often improperly regarded as blanket privileges, allowing for a wide scope of protection, a class privilege merely establishes which party bears the onus in disproving the existence of the privilege: "[i]n a class privilege, there is a prima facie presumption of inadmissibility because of policy reasons where the relationship has been established to be within the class. ${ }^{4}$ The presumption of inadmissibility is in accord with the status these privileges are given in our legal system.

The privilege is held by the client and serves to protect communications between a solicitor and a client from disclosure. More specifically, "[a] communication between a solicitor and a client, of a confidential nature and related to the seeking, forming, or giving of legal advice, is privileged information." The essence of this rule is that communications that meet the above requirements will be inadmissible in court proceedings. The formulation of the substantive rule was articulated by Lamer J., as he was then, in Descôteaux $v$. Mierzwinski and Attorney-General of Quebec:

1. The confidentiality of communications between solicitor and client may be raised in any circumstances where such communications are likely to be disclosed without the client's consent.

2. Unless the law provides otherwise, when and to the extent that the legitimate exercise of a right would interfere with another person's right to have his communications with his lawyer kept confidential, the resulting conflict should be resolved in favour of protecting the confidentiality.

3. When the law gives someone the authority to do something which, in the circumstances of the case, might interfere with that confidentiality, the decision to do so and the choice of means of exercising that authority should be determined with a view to not interfering with it except to the extent absolutely necessary in order to achieve the ends sought by the enabling legislation.

4. Acts providing otherwise in situations under para. 2 and enabling legislation referred to in para. 3 must be interpreted restrictively. ${ }^{6}$

The framing of the substantive rule in Descôteaux, although maintaining the stature of the rule, does include the potential to override the privilege in certain circumstances.

Solicitor client privilege is a time-honoured component of our modern legal system. With its roots tracing back to the sixteenth century, solicitor client privilege is the oldest 
confidential communications privilege. ${ }^{7}$ Originally held to be a functional rule of evidence, this privilege has evolved to a "fundamental civil and legal right" ${ }^{3}$ and is now considered to be a "substantive rule of law." In demonstrating the sanctity of the class privileges one need only consider the comments of L'Heureux-Dubé J.: "[a] class privilege presents many impediments to the proper administration of justice and, for that reason, has not been favoured in Canada and elsewhere in criminal trials. A class privilege is a complete bar to the information contained in such records ... and the onus to override it is a heavy one indeed." ${ }^{10}$ The comment denotes a clear respect for the concept of a class privilege, while at the same time demonstrating a disdain for its operation. The idea that this conflict can coexist within the same rule is insightful and it demonstrates the Court's difficulty in dealing with solicitor client privilege. The willingness to concede an "occasional injustice" "1 in order to protect the integrity of these kinds of privilege further demonstrates the regard for such class privilege.

The purpose of the privilege is to ensure the effective operation of the administration of justice. By providing to individuals a guarantee that complete disclosure to their solicitor can occur, solicitor client privilege plays a vital role in our legal system. The classic statement concerning the rationale for solicitor client privilege frames its function in a deceptively simplistic manner:

The foundation of this rule is not difficult to discover ... it is out of regard to the interests of justice, which cannot be upholden, and to the administration of justice, which cannot go on without the aid of men skilled in jurisprudence, in the practice of the courts, and in those matters affecting rights and obligations which form the subject of all judicial proceedings. If the privilege did not exist at all, every one would be thrown upon his own legal resources. Deprived of all professional assistance, a man would not venture to consult any skilful person, or would only dare to tell his counsellor half his case. ${ }^{12}$

The last portion of this quote is particularly relevant to this article. As will be demonstrated in Part IV, the inability to be forthcoming is one of the very practical problems for the police under the current structure of solicitor client relations with the Crown.

The requirements for solicitor client privilege are straightforward and easily understood though the Wigmore articulation: "Where legal advice of any kind is sought from a professional legal adviser in his capacity as such, the communications relating to that purpose, made in confidence by the client, are at his instance permanently protected from disclosure by himself or by the legal adviser, except the protection be waived. ${ }^{13}$ The key to understanding this definition and how it relates to the role of the Crown is distinguishing the varying roles of the Crown. A Crown who is prosecuting a matter is first and foremost an

John Sopinka, Sidney N. Lederman \& Alan W. Bryant, The Law of Evidence in Canada, 2d ed. (Toronto: Butterworths, 1999) at 728.

McCarthy Tetrault v. Ontario (1993), 95 D.L.R. (4th) 94 (Ont. Prov. C.E.) [McCarthy].

Weiler v. Canada (Department of Justice), [1991] 46 F.T.R. 163 (T.D.) at para. 10 [Weiler].

R. v. Gruenke, [1991] 3 S.C.R. 263 at 292 [Gruenke].

M.(A.) v. Ryan, [1997] I S.C.R. at para. 32. [Ryan].

Greenough v. Gaskell (1833), 39 E.R. 618 at 620 (Ch. Div.) [Greenough].

John Henry Wigmore, Evidence in Trials at Common Law, vol. 8, 3d ed., rev. by J.T. McNaughton (Boston: Little, Brown, 1961) at 554. 
officer of the court and could not be considered a professional legal advisor. As noted by The Royal Commission on the Donald Marshall, Jr., Prosecution: "the Crown prosecutor occupies what has sometimes been characterized as a quasi-judicial office, a unique position in our Anglo-Canadian legal tradition."14 In instances where the issue of solicitor client privilege arises between the police and a Crown who is acting as a prosecutor, the Crown cannot be considered a solicitor of the police for the purpose of obtaining privilege. As will be seen, several cases have espoused this idea. ${ }^{15}$

On the other hand, where the Crown is not prosecuting the matter before the court and has merely provided advice to the police, there is nothing in the requirements for solicitor client privilege that would appear to exclude this relationship. The Crown is being consulted by the police in the Crown's capacity as a legal advisor. Providing that the communications offered meet the requirement of being an opinion, this situation is a solicitor client relationship. The Integrated Proceeds of Crime Sections of the Royal Canadian Mounted Police (RCMP) throughout Canada have Department of Justice lawyers working as in-house counsel. Providing that they only advise on matters, and are not prosecuting, these Department of Justice lawyers are within the definition of solicitor. In no way is this example in conflict with the traditional rule. By delineating the precise role of the Crown as either a prosecutor or an advisor, the traditional rule of solicitor client privilege can remain coherent in the police/Crown context.

\section{A. Exceptions to Solicitor Client Privilege}

Just as all rules in law are not absolute, solicitor client privilege is no exception. In certain instances, this rule can be overridden pursuant to the traditional exceptions: waiver, future crimes, or innocence at stake. ${ }^{16}$ Although not a formal exception, a further technique is routinely used and finds that the communications were neither an opinion nor given within the requirements of the rule for privilege. Although this would appear obvious, it is worthy of note as the courts routinely use this technique in the police/Crown context. As noted by Cory J. in Smith $v$. Jones, the list of exceptions to the solicitor client rule is not closed: "[the list] may be expanded in the future."17 Each one of the recognized exceptions has been

Nova Scotia, vol. 1 (Halifax: The Commission, 1989) at 227-28 [Marshall Inquiry].

For commentary on the principles underlying the traditional role of the Crown as an impartial officer of the court, see Boucher v. The Queen, [1955] S.C.R. 16, specifically the often-cited comments of Rand J., which emphasized the role of the Crown as not being rooted in obtaining a conviction, but rather, to provide the complete factual account of a matter in a fair and impartial manner. Also, in relation to concerns surrounding Crown objectivity, their ability to fulfill their public role to the court and the potential for erosion of their impartiality due to a close working relationship with law enforcement (see Ontario, Report of the Commission on Proceedings Involving Guy Paul Morin, vol. 2 (Toronto: Ministry of the Attorney General, 1998) at 909, 911, and 1069-70, which espoused that Crown involvement in the investigative aspect of a police matter can lead to a loss of objectivity and ultimately impair their ability to discharge their role as an officer of the court in an independent manner).

16. Another exception, public safety, does exist. However, as it is not directly relevant to this article, it will not be addressed here.

17 [1999] 1 S.C.R. 455 [Smith]. 
influenced by s. 11(d) of the Canadian Charter of Rights and Freedoms, which relates to the right to make full answer and defence. ${ }^{18}$

\section{WAIVER}

There are two components to the waiver exception to solicitor client privilege: voluntary waiver and implied waiver. To voluntarily waive the privilege, it must be shown that the holder "(1) knows of the existence of the privilege, and (2) voluntarily evinces an intention to waive that privilege."19 Implicit waiver is related to the concept of fairness. Where a portion of a legal opinion is disclosed or the opinion is affirmatively argued before the court, then it would be unfair to shield the legal advice from the opposing party. ${ }^{20}$ In the police/Crown context, two recent cases explored the notion of implicit waiver by the RCMP, who asserted good faith in relying on the legal opinions provided to them by the Crown. ${ }^{21}$

\section{FUTURE CRIME}

The future crime exception to solicitor client privilege is better expressed not as an exception, but as a "'negation' of solicitor client privilege." ${ }^{22}$ Solicitor client privilege requires that there be both a "professional confidence and professional employment, but if the client has a criminal object in view in his communications ... one of these elements must necessarily be absent. The client must either conspire with his solicitor or deceive him." ${ }^{23}$ Framed in this manner, the future crime exception is closely related to the inability to find a privilege based on a failure to satisfy the requirements of a privileged communication.

\section{INNOCENCE AT STAKE}

The innocence at stake exception is the most controversial exception to this rule. The courts have recently outlined the test that must be met in order to invoke this exception. The leading case on this exception is $R$. v. Brown, ${ }^{24}$ which applied the test set out in $R v$. McClure. ${ }^{25}$ In Brown, the Court stated that once an accused has established that the privileged information is not available from any other source and that without it he cannot raise a reasonable doubt, the judge must ask whether the privileged communications "could raise a reasonable doubt as to his guilt ... [and] ... whether, in fact, it is likely to raise a reasonable doubt as to the guilt of the accused." ${ }^{26}$ The jurisprudence surrounding the application of the innocence at stake test is confusing in its own right, and is worthy of being explored in another article.

Part 1 of the Constitution Act, 1982, being Schedule B to the Canada Act 1982 (U.K.), 1982, c. 11, s. 24 [Charter].

S\&K Processors Ltd. v. Campbell Ave. Herring Producers Ltd. (1983), 45 B.C.L.R. 218 (S.C.) at para. $6[S \& K$ Processors $]$.

Ibid.

Campbell, supra note 3; Regina v. Creswell (2000), 149 C.C.C. (3d) 286 (B.C.C.A.).

Paciocco \& Stuesser, supra note 5 at c. 7, s. 2.1.

R. v. Cox and Railton (1884), 14 Q.B.D. 153 at 168 [Cox].

[2001] 2 S.C.R. 185 [Brown].

[2001] 1 S.C.R. 445 [McClure].

Brown, supra note 24 at para. 4 . 


\section{GENERAL EXCEPTION}

The final exception of failure to satisfy the elements of solicitor client privilege will result in a finding of no privilege and, as such, the information will be disclosed. One obvious example would be an opinion from an individual who is not a practicing lawyer. In that case, any communication made could not engage the rule and would be exempt. Not as obvious would be communications from in-house counsel. This situation is particularly on point for this article, as the concept of the police using police officers, who are practicing lawyers, for legal advice engages an inquiry into exactly the capacity in which such communication was made.

This kind of distinction was noted in R. v. Campbell: ${ }^{27}$ "[i]n private practice some lawyers are valued as much (or more) for raw business sense as for legal acumen. No solicitor-client privilege attaches to advice on purely business matters even where it is provided by a lawyer." ${ }^{28}$ Determining whether or not a communication will be covered by solicitor client privilege "depends on the nature of the relationship, the subject matter of the advice and the circumstances in which it is sought and rendered."29 This has become the modern template in determining whether solicitor client privilege exists.

The traditional concepts of solicitor client privilege and its exceptions are relatively straightforward. When the proper components are satisfied, the privilege will be found to exist. If one of the exceptions applies, then the court will revoke the privilege. This kind of application in the context of criminal defence relationships or civil litigation can be problematic at times; however, within the overall body of jurisprudence most issues merely require an interpretation of the recognized principles. The traditional model has had the benefit of hundreds of years of scrutiny and interpretation which provide a high degree of clarity in its application. ${ }^{30}$

\section{THE CONFUSION IN THE JURISPRUDENCE}

The traditional rule provides for a very straightforward approach to issues surrounding solicitor client privilege. Regrettably, this coherent structure becomes confusing when solicitor client privilege is applied in the non-conventional context of the police/Crown

\section{$27 \quad$ Supra note 3.}

$2 \times \quad$ Ibid. at para. 50 .

2) Ibid.

31) It is worth highlighting the distinction between solicitor client privilege and what has become known in Canadian jurisprudence as work product privilege. Work product privilege relates to protection afforded to the working aspects of the Crown's file. Items such as notes in relation to witness testimony, letters, memoranda, and other general correspondence that do not of themselves contain any real evidence, but merely form the process of how the Crown prepares their case, can be considered as work product. The definitive statement on work product privilege was contained in United States Supreme Court decision in Hickman v. Taylor 329 U.S. 495 (1947). In Canada, work product privilege has been recognized by the Supreme Court of Canada as material of the kind noted above, which would not be disclosed under normal circumstances. The touchstone is really a consideration of the content of the material in question (see $R . v . O^{\prime}$ Connor. [1995] 4 S.C.R. 411). It would seem that the material that could be protected by work product privilege would not equate to the kinds of materials for which solicitor client privilege could be used to protect, such as investigative strategies or advice provided by the police. Certainly these would fall outside of the narrow application of work product privilege. 
relationship. The police sometimes utilize the Crown as their source for legal advice in relation to operational investigative issues. As such, the Crown acts as legal counsel on behalf of the police, thereby creating a novel solicitor client relationship. In demonstrating the inconsistent application of the traditional rule in the police/Crown context, it is helpful to place the relevant cases into one of the following categories: analogous situations, solicitor client privilege found, solicitor client privilege found and revoked, and solicitor client privilege not found. Although categorization of the cases denotes a finding for or against privilege, a closer analysis of the reasoning does reveal a consistent pattern regardless of the finding. Before turning to the categories, a brief look at the relevant legislation will set the stage for the confusion surrounding solicitor client privilege between the police and Crown.

\section{A. LegisLATION}

Some of the enabling legislation which outlines the duties of Crown prosecutors across Canada does contain provisions which specify that the Crown is to provide legal advice to the police. At the federal level, The Department of Justice Act, s. 5(b) states that, among other responsibilities of the Attorney General, he or she "shall advise the heads of the several departments of the Government on all matters of law connected with such departments." ${ }^{\prime 3}$ This section has been used recently as a basis for the court espousing a general proposition that there is a solicitor client relationship between the RCMP and the federal Crown. Justice Humphries of the British Columbia Supreme Court specifically relied upon the Department of Justice Act when stating "[a]t the outset, I should say I am of the view that there is solicitor/client privilege that arises as between the RCMP and its legal advisors." ${ }^{\prime 2}$ The Department of Justice Act was also used in Campbell as a basis to establish the existence of a solicitor client relationship between the RCMP and the Crown. ${ }^{33}$

At the provincial level, the relevant legislation provides another dimension to this issue. The Nova Scotia Public Prosecutions Act makes specific reference to the duties of the Crown, including "[advising] police officers in respect of prosecutions generally or in respect of a particular investigation that may lead to a prosecution when the police request such assistance." ${ }^{34}$ In Quebec, An Act respecting Attorney General's prosecutors sets out the duties of the Crown to include "[advising] peace officers and persons entrusted with law enforcement acting in the performance of their duties on any matter under the jurisdiction of the Criminal Code or of any penal provision of a law or regulation of Quebec." ${ }^{35}$ It would appear that in Nova Scotia and Quebec, Crown attorneys are empowered to provide advice to the police.

The remainder of the provinces appear to have no equivalent in their respective statutes. In fact, a survey of the various provincial legislation governing the powers of the Crown prosecutor did not produce one other statute that specified a role of the Crown to include advising the police. Under the heading of, inter alia, duties of the Crown, no reference could

R.S.C. 1985 , c. J-2, s. 5

R. v. Creswell, [1998] B.C.J. No. 1770 at para. 15 (QL) [Creswell I].

Campbell, supra note 3.

R.S.N.S., 1990, c. 21, s. 4(d).

R.S.Q. 1969 , c. S-35, s. 4(i). 
be found for advising the police in the following statutes: Crown Attorneys $\mathrm{Act}^{36}$ of Ontario, Crown Prosecutors $\mathrm{Act}^{37}$ of New Brunswick, Crown Attorneys $\mathrm{Act}^{38}$ of Manitoba and the Crown Counsel $\mathrm{Act}^{39}$ of British Columbia. The rest of the Provinces and Territories Saskatchewan, Alberta, Prince Edward Island, Newfoundland and Labrador, North West Territory, Yukon Territory, and Nunavut - did not contain any legislation that outlined the duties of a Crown prosecutor.

Interestingly, part of the basis for the confusion surrounding the proposition that the Crown is not to advise the police are several statutes that make specific reference to the role of the Crown as including the provision of legal advice to Justices of the Peace. ${ }^{40}$ This specific inclusion, along with the omission of a provision that outlines the Crown's duty to advise the police, can reasonably be interpreted to indicate that no such duty exists for the Crown. There is little reference to the statutory authorities in the cases that address solicitor client privilege between the police and Crown.

In one of the rare examples of addressing the meaning of s. 4(d) of the Public Prosecution Act in Nova Scotia, Batiot J. of the Provincial Court of Nova Scotia took the position that the advice component related more to the Crown's traditional role of providing an opinion on the sufficiency of evidence for charging. He continued to support this narrow interpretation, by noting that "[t]he Statute is silent as to privilege." "With respect, the omission of privilege from the statute does not in any way assist in construing s. 4(d) in a narrow manner. A plain reading of the section clearly denotes two functions for the Crown: charge advice and investigative advice. ${ }^{42}$ The latter would clearly come into the sphere of a legal opinion and relates to what role the Crown is occupying. By acknowledging the dual roles of the Crown and understanding the traditional rule, there would be no need to construe 4 (d) in a narrow manner.

Even with the bulk of the provincial legislation silent on whether the Crown can advise the police, the fact remains that if the Crown is not acting in a prosecutorial manner, there is no conflict with the legislation. If the actions of a Crown attorney come within the definition of privileged relationship, then privilege should be found. Viewed from this perspective, unless there is a body of legislation that specifically precludes Crown attorneys from privileged relationships with the police, then the legislation, or lack thereof, on this issue must be seen as being congruent with the traditional rule.

36. R.O. 1990, c. C-49, s. 11.

$37 \quad$ R.S.N.B. 1973 , c. C-39, s. 4.

$38 \quad$ R.S.M. 1987 , c. C-330, s. 5.

39 R.S.B.C. 1996, c. 87 , s. 4.

40 See Crown Attorneys Act, R.S.O. 1990, c. C-49, s. 11 (h) and The Crown Attorneys Act, supra note 38, s. 5(1)(b).

4 Regan Application, supra note 2 at para. 28.

42 Public Prosecutions Act, supra note 34. 


\section{B. CATEgoRizing THE JURISPRUDENCE:}

\section{A PATCHWORK OF INCONSISTENCY}

To extract a coherent principle from the body of jurisprudence is more difficult. Although support for the principle that the Crown can engage in a solicitor client relationship with the police can be extracted from almost every case, some remain beyond supporting this proposition. Whether the Court found the privilege to exist, found the privilege to exist and then revoked it, or did not find the privilege to exist at all, the role of the Crown as prosecutor or advisor provides the basis for the consistency within all of the reasons. Regrettably, this accidental consistency runs throughout the four categories of cases without ever being articulated expressly. This failure to precisely define the principle is a significant reason for the confusion in the jurisprudence on this issue.

\section{ANALOGOUS PRINCIPLES}

There is a body of case law that forms the basis for the core arguments surrounding the issue of whether solicitor client privilege between the police and the Crown could or could not exist. The reasoning from these types of cases is routinely used to establish the existence of a privileged relationship between the police and the Crown. These cases address the issue from analogous situations that are purported to be akin to the police/Crown context (for example, communications between other government departments and their legal advisors). The use of analogous examples may have had more to do with the difficulty in finding cases that provided compelling, on-point reasoning to this issue in its early stages. Although these analogous relationships may appear to emulate the police/Crown relationship, they do not take into account the special role of the police or that of the Crown in the administration of justice. Much of the Canadian jurisprudence on the police/Crown solicitor client privilege issue draws its reasoning back to these kinds of cases.

One of the earliest cases is the 1979 Alberta Supreme Court (Appeal Division) decision in R. v. Medicine Hat Greenhouses Ltd. ${ }^{43}$ Although not specific to the police/Crown context, it established the principle that in-house consultation between various sections of the government and government lawyers would be protected by solicitor client privilege. The privileged communications in question related to "the Crown ... consulting its solicitors in the Department of Justice and obtaining legal assistance from them." 44 Medicine Hat is not a definitive authority for holding that there is privilege between the police and the Crown, but it is routinely cited as a basis for that finding.

In Waterford v. The Commonwealth of Australia, the High Court of Australia upheld the concept of intra-governmental solicitor client privilege. ${ }^{45}$ The parties there consisted of officers of a government department who had consulted with government legal advisors in another branch. A similar finding of the Federal Court in Canada in Weiler $^{46}$ is also used as a basis to support solicitor client privilege between the police and the Crown. There, the 
Court held that legal profession privilege did exist between lawyers in the office of the Attorney General of Canada and the Executive branch of the Government of Canada. One must remember that at the time of these decisions there was little if any case law in Canada on solicitor client privilege outside of the civil and criminal defence spheres.

The principle that a privileged relationship exists between solicitors in a government department and clients in another department is entirely in keeping with the traditional rule of solicitor client privilege. In Medicine Hat, the Court found that the solicitors were Department of Justice lawyers and that the clients were the Crown. It is significant to note that the finding of privilege in Medicine Hat in no way attempts to abrogate the traditional requirements for solicitor client privilege. This is important to consider, as several cases routinely find that the Crown prosecutor is not a solicitor for the purposes of privilege. However, that determination does not detract from the concept that a Crown advisor is a solicitor for the purposes of privilege.

\section{SOlicitor Client PRivilege Found}

The next category of cases includes those where only a cursory analysis of the issue is conducted, but where a finding nonetheless is made of solicitor client privilege between the Crown and the police. There are only a handful of cases that have found the existence of such a relationship and that do not revoke the privilege pursuant to one of the exceptions. The small number of cases in this category demonstrate both the court's difficulty in determining the existence of solicitor client privilege between the police and the Crown and in also upholding such privilege once it has been identified.

In R. v. Heron, ${ }^{47}$ the privileged communications in question concerned a memo from a Crown prosecutor to an investigating officer. The judge did acknowledge the conflicts in the case law surrounding this issue, but made no attempt to resolve or explain this dilemma. The only analysis conducted appears to represent Verte J.'s interpretation of the state of the law. Justice Verte's rationale for finding the existence of a privilege was stated as follows:

In my opinion the relationship between a prosecutor and a police investigator cannot be categorized for all purposes and at all times as a "solicitor-client" relationship. It may be for one purpose; it may not be for another. If the communications consist of alleged facts and particulars of a case, then no one I think can say that those would not be subject to disclosure under current law. If, however, the communications consist of legal opinions, advice as to trial tactics, consideration of prosecutorial options, then they would, in the absence of any one of the above-noted exceptions, be subject to the privilege. That is because, in the latter instance, the investigator is seeking the advice and opinion of the prosecutor as "lawyer", as opposed to exchanging information as "co-workers" in the administration of justice. The investigator then becomes a "client" as opposed to being an "associate" of the prosecutor. ${ }^{48}$

This cursory analysis of how the police/Crown come within the solicitor client rule does little to assist the development of a coherent understanding of the solicitor client privilege rule in this context. The facts do not indicate whether the Crown in question was in fact acting as 
an advisor or as a prosecutor. However, the comments of the judge delineating the different roles of the Crown are the key factor in determining whether or not a privilege exists. Although never articulated in terms that precisely define the Crown as either an advisor or a prosecutor, the reference to multiple duties supports the proposition that the finding of privilege will be based on the role in which the Crown was engaged. It is also worthy of note that the judge in Heron relied upon the principle of intra-governmental privilege from Medicine Hat. ${ }^{49}$

The most recent case on privilege that falls into this category, R. v. Chan, ${ }^{50}$ is a 2002 decision from the Court of Queen's Bench of Alberta. That case dealt with the police attempting to claim solicitor client privilege over draft affidavits that were prepared in consultation with a Crown attorney. In support of finding that privilege can exist between "Department of Justice lawyers and their respective clients." "J1 Justice Sulyma cited Medicine Hat and Re Regina and Gray.$^{52}$ Medicine Hat supported the general principle that in-house consultation between various sections of the government would be protected by solicitor client privilege. ${ }^{53}$ Gray involved s. 37 of the Canada Evidence Act and the requirements for Crown Immunity. In fact, Gray made specific reference to not disturbing the lower court's rejection of solicitor client privilege between the police and Crown. ${ }^{54}$ Regrettably, the reasoning in this decision is more confusing than helpful.

In Chan, the lawyer in question was clearly acting in an advisory capacity, as she was reviewing draft affidavits. Although an employee of the Department of Justice, she was an in-house counsel to the Integrated Proceeds of Crime Unit. ${ }^{55}$ This distinction, along with the judge accepting the principle from Medicine Hat, provides support for the proposition that a privileged relationship can exist between the police and a Crown who is acting in an advisory capacity. The only difficulty in extracting this principle from Chan was that the judge also cited Gray as an authority for finding privilege. The reliance on Gray, which rejected a claim of privilege, demonstrates the confusing references that make extracting a coherent principle difficult. That being said, the main reasons from Chan support the position that privilege can exist between the police and the Crown functioning as an advisor.

\section{Solicitor Client Privilege Found and Revoked}

This category of cases includes decisions that find the existence of a privileged relationship between the police and the Crown, but revoke the privilege. The basis for the finding of privilege is either an assumption of its existence or reasoning that is marginal. Without a thorough analysis by the judge or a proper challenge from the defence, the existence of a privileged relationship is often unchallenged or taken for granted. The cases in this category routinely pass over the first step of establishing the existence of the privilege.

R. v. Chan (2002), 325 A.R. 208 [Chan].

Ibid. at para. 10.

(1993), 79 C.C.C. (3d) 332 (B.C.C.A.) [Gray], leave to appeal to S.C.C. refused 83 C.C.C (3d) vi.

Chan, supra note 50 at para. 3 
By avoiding this step, which would arguably be more difficult because of the confusion in the jurisprudence, the arguments routinely move to the seemingly easier analysis of whether or not there exists any potential exception.

Either through waiver, future crimes, innocence at stake, or the definitional exception, the courts routinely disclose the privileged communications. Taken from this perspective, it is important to consider the end result of a finding of revocation of the privilege - the existence of the privilege is a non-issue. There is little controversy created or little reasoning spent when making a finding of privilege while ultimately knowing that it will be revoked. Unfortunately, the by-product of an inadequate analysis is that a coherent articulation of the rule is never made. However, upon closer examination the cases in this category support the existence of a privileged relationship between the police and the Crown in an advisory capacity.

In Re: Attorney-General of Canada and Sander, ${ }^{56}$ the British Columbia Court of Appeal acknowledged the practice of assuming the existence of the privilege. There, the issue concerned notes and opinions provided to Revenue Canada investigators by the Department of Justice. On the issue of solicitor client privilege over those documents, Wood J. observed that "[t]he trial judge assumed ... that the material so described was subject to a common law claim of solicitor-client privilege. ${ }^{157}$ The Court went on to allow the appeal on other grounds and did not disturb the lower Court's ruling on solicitor client privilege.

The revocation component in Sander was not addressed by the Court of Appeal. However, in obiter dicta, Wood J. made reference to a related decision in Regina $v$. Gray ${ }^{58}$ and inferred that any privilege should yield as "solicitor-client privilege ... between Crown counsel and police officers conducting a 'reverse sting' operation in a drug investigation must yield in that case to the right of the accused to make full answer and defence." 59 Although Sander does not provide strong support for a coherent principle, it does not weaken the argument that the role of the Crown is determinative in establishing whether a privileged relationship exists between Crown advisors and the police.

In Creswell $1,{ }^{60}$ the privileged communications concerned several opinions provided by various Department of Justice lawyers about the legality of a store-front money laundering operation whereby the police operate a business and pose as money launderers. Defence counsel conceded the existence of solicitor client privilege between the Department of Justice and the Commissioner of the RCMP. ${ }^{61}$ In the context of privilege between investigators and the Crown, the Court stated:

[a]t the outset, I should say I am of the view that there is solicitor/client privilege that arises as between the RCMP and its legal advisors. This is not the situation like R. v. Girouard (1982), 68 C.C.C. (2d) 261 , where the relationship is one of prosecutor and investigating policemen. The circumstances in which I am asked to

(1994), 90 C.C.C. (3d) 41 [Sander], rev'g 79 C.C.C. (3d) 63 (B.C.S.C.).

Ibid. at 53 .

(1992), 74 C.C.C. (3d) 267 (B.C.S.C.) [Gray l].

Sander, supra note 56 at 72 .

Creswell l, supra note 32 .

Ibid. at para. 5 . 
consider the existence of the privilege involved the relationship between representatives of a government body and its legal advisors, a relationship which has been held many times to give rise to the same privilege that arises between a lawyer and client. ${ }^{62}$

In the context of investigators and their legal advisors, the court distinguished R. v. Girouard and then appeared to uphold the existence of the privilege on the historical in-house counsel model. The Court then immediately turned to a revocation analysis.

On the issue of exceptions to the privilege, the Court found that the police had relied on good faith and had placed the legal opinion provided by the Department of Justice lawyer before the courts: "By relying on those opinions as at least a partial reason for having embarked on this operation, the RCMP have, in my view, waived the privilege." ${ }^{\prime \prime 3}$ The Court also indicated that the communications in question would not be protected as "there appears to have been little in the way of legal opinions and advice provided to the RCMP." ${ }^{64}$ The definitional exception creates confusion in extracting a coherent principle. If the Judge felt that the communications in question did not meet the elements to engage the privilege, then why proceed into any analysis of potential exceptions? As there is no indication that this was done in the alternative, the only effect of such an inquiry is to obscure any coherent principle that might otherwise be contained in this case.

At the Court of Appeal, the implicit waiver finding was rejected and the matter was returned to trial on the issue of whether the privileged information was properly disclosed pursuant to the innocence at stake exception. ${ }^{65} \mathrm{~A}$ similar process was used in Creswell 1 , the sister case to $R$. v. Desabrais. ${ }^{66}$ It could be true that the better arguments to be made might be based in waiver; however, with no reasoning to support the existence of solicitor client privilege, all that the waiver arguments have done is somehow legitimize a concept that has not been proven.

It is worth noting that the lack of inquiry into any existence of solicitor/client privilege between the police and the Crown continued on appeal of the Creswell 1 case. The British Columbia Court of Appeal did make reference to Campbell and to the Supreme Court of Canada's finding that a privileged relationship could exist between the police and Crown. However, little analysis was conducted to establish the existence of a solicitor client relationship. The Court of Appeal dealt with this element by indicating that "it was common ground that the legal opinions obtained by the RCMP were privileged communications." ${ }^{167}$ With the benefit of the reasons from Campbell, the Court of Appeal could have used the opportunity to provide a more thorough analysis of this concept. Again, by adopting the common ground, we are without a well-reasoned basis to support the existence of a solicitor client relationship in the police/Crown context. 
In support of a coherent principle, it is important to note that the Crown was acting in an advisory capacity when the legal opinions were given. The legal opinions were provided both "before the commencement of this operation ... and during the course of the operation." 68 Even if the Crown who provided those opinions was in fact the Crown who subsequently prosecuted the matter, their capacity at the time at which the opinions were given was clearly advisory. Within the traditional definition of solicitor client privilege, the Crown in Creswell $l$ was a solicitor, and this case does support the position that a Crown counsel acting in an advisory role can be considered a solicitor for the purposes of a privileged communication.

Although the exact principle was never articulated, the judge in Creswell 1 appeared to acknowledge the importance of the multiple roles of the Crown. By acknowledging $R$. $v$. Girouard as a situation in which "the relationship [was] one of prosecutor and investigating policemen," The judge proceeded to use the principles from Medicine Hat and Weiler, which support the premise that in-house government counsel can provide privileged advice. Unfortunately, the references to the analogous cases end up diluting any specific statement about the police/Crown context. Ultimately, any chance of a coherent principle is lost amid the subsequent waiver analysis that determined that the communications were not privileged and then proceeded to revoke such privilege. Notwithstanding the confusing revocation analysis, Creswell 1 does support the principle of a privileged relationship between the police and a Crown who is acting as an advisor.

The case which has been recognized as the leading authority on the issue of solicitor client privilege between the police and Crown is Campbell. ${ }^{70}$ The privilege communications in this case concerned opinions given by the Department of Justice to the RCMP about the legality of a "reverse sting," where the police pose as vendors of drugs. Although not the main issue, the Supreme Court of Canada entered into a moderate analysis of the existence of such a privilege.

In speaking for the Court, Binnie J. indicated the practical basis for finding the existence of a privileged relationship: "It is of great importance, therefore, that the RCMP be able to obtain professional legal advice in connection with criminal investigations without the chilling effect of potential disclosure of their confidences in subsequent proceedings."71 From the perspective of the police, this could be considered a positive step in supporting the existence of a privilege between the Crown and the police. The difficulty with Binnie J.'s comment is that it does not make specific reference to the Crown as the source for the legal advice, but espouses the general need for the police to obtain legal advice.

Justice Binnie refers to the general jurisprudence, noting the requirements to be met for solicitor client privilege in the traditional context, as stated in Wigmore: "Where legal advice of any kind is sought from a professional legal adviser in his capacity as such, the communications relating to that purpose, made in confidence by the client, are at his instance 
permanently protected from disclosure by himself or by the legal adviser, except the protection be waived." ${ }^{72}$ The only other specific reference to jurisprudence relating to solicitor client privilege between the Crown and the police was distinguishing the finding of no privilege between the Crown and police in $R$. v. Girouard.$^{73}$ It would seem that this constitutes the basis for establishing privilege between the police and the Crown. The limited explanation provided again fails to articulate a coherent principle on privilege in this context and provides little reconciliation of the jurisprudence.

It is unclear whether the lawyer from the Department of Justice lawyer was actually prosecuting the case or merely consulted in an advisory capacity. The Court's reference to the advising lawyer as one who "works for an 'in-house' government legal service"74 suggests that the situation is similar to that in $\mathrm{Chan}^{75}$ and the RCMP Integrated Proceeds of Crime Unit. Further support for that interpretation can be found in the Court of Appeal for Ontario decision, where the relationship was characterized as "...[a] relationship with a lawyer in the Crown law office." ${ }^{76}$ Again, there is no reference to the advising lawyer as the prosecutor of the case. The absence of any reference to the Crown as a prosecutor supports the position that the Crown in Campbell was acting in an advisory capacity.

Aside from espousing that the police should have access to legal advice, there was nothing further stated within the case that would assist in extracting a coherent principle. In fact, the reference to Girouard makes the reasoning in this case more complicated than it needed to be. By distinguishing Girouard as holding that no privilege can be based on the police as agents of the Crown or on the police as a witness trying to claim privilege, the Court unnecessarily analyzed Girouard more than it needed. What could have been pointed out was that the Crown in Girouard was a prosecutor speaking with a witness about his testimony, whereas the Crown in Campbell was an advisor, giving legal advice about how the investigation could be conducted. By failing to note this distinction, the Supreme Court of Canada missed an opportunity to clearly enunciate the principle that a privileged relationship can exist between the police and a non-prosecuting Crown. Having noted that, however, the reasoning in Campbell does support the existence of a solicitor client relationship between the police and the Crown who is an advisor.

In $R . v$. Guilbride, the privileged communications in question related to a series of documents exchanged between the Crown and the police in relation to an assessment of a potential witnesses's evidence. Justice Arnold of the British Columbia Provincial Court merely acknowledged that " $[t]$ he Crown made general submissions on the nature of ... solicitor/client privilege as it may exist between Crown counsel and the police." ${ }^{.77}$ With no further analysis, Arnold J. then immediately proceeded to an analysis of the exceptions to the privilege. With no rationale provided for the finding of privilege, this case offers no assistance in understanding the basis upon which such a ruling could be made.

Wigmore, supra note 13 at 554 .

(1982), 68 C.C.C. (2d) 261 (B.C.S.C) [Girouard].

Campbell, supra note 27 at para. 49.

Supra note 50.

R. v. Campbell (1997), 115 C.C.C. (3d) 310 at 331 [Campbell 2].

R. v. Guilbride, 2001 BCPC 238 [Guildbride]. 
The reasoning used in the analysis of whether the privilege had been revoked only serves to confuse the entire issue of privilege. Although the issue of waiver was raised in the context that partial disclosure of the privileged communications should necessitate a finding of implicit waiver, the Court found that the documents were "purely factual as documenting the police's view of the situation of the time... They do not contain legal advice or issues posed by the police to the Crown upon which they sought advice." 78 The confusion with this reasoning is that if no privilege could be claimed for the communications, then why accept counsel's joint submission of the existence of such a privilege? Also, how could the Judge proceed into an analysis of exceptions to the privilege when he found that the communications were not in fact covered by privilege?

Ultimately, the communications were determined not to be relevant and were not disclosed. By failing to analyze the issue in the correct order by examining the existence of the privilege first, Guilbride demonstrates the confusion that is created as a result of this kind of analysis. A by-product of this confusion appears to be an insufficient inquiry into whether the privilege actually exists. This case could have been placed in a category that finds that no privilege exists, but was left in the found and revoked category because it demonstrates both the lack of clarity in the cases and the incoherent application of the general principles surrounding solicitor client privilege.

With all of the cases in this category skipping over a well-reasoned analysis into whether there exists any privilege and immediately moving onto the waiver component, the jurisprudence remains unclear. Ironically, those cases that purport to find the existence of a privileged relationship apparently are not helpful in establishing a coherent basis for understanding the privilege. However, the underlying principle in these cases was again that the precise role of the Crown will be determinative in establishing the existence of a privilege. Interestingly, even with the finding from Campbell, we are still without a precedent at the Supreme Court of Canada level, which has upheld the entire police/Crown privilege issue as both the finding of the relationship and the protecting of subsequent communications. In practice, it would appear, therefore, that the ability of the police to maintain privileged communications with the Crown is dubious.

\section{Solicitor Client PRivilege Not Found}

The final category of cases are those where the court found that no solicitor client privilege existed between the police and the Crown. The reasoning contained in these cases ranges from a flawed analysis to a comprehensive survey of the relevant jurisprudence. In the cases where a comprehensive analysis was conducted, the arguments presented against the finding of privilege are well reasoned, but still fail to conceptualize a coherent principle that explains the inconsistencies in the jurisprudence. Even though the courts still wrestle with such inconsistencies, the reasoning from the cases in this category is the most compelling for establishing that privilege between the police and the prosecuting Crown does not exist.

However, the reasoning used is also in accord with the principle that a solicitor client relationship between the police and a Crown who is an advisor can exist. Part of the reason 
for not finding privilege is that the courts confuse the reasoning from the other cases. By failing to understand the principle that runs throughout all of the cases on this topic, the courts are unable to properly apply the principles. Having noted that, there are two cases in this category that are based on a well-reasoned analysis. Although they do not articulate the specific principle, their reasoning is clearly founded on the premise that a privileged relationship between the police and a Crown advisor can exist.

In Girouard, the Court relied more on logical reasoning than on jurisprudence to hold that there could be no solicitor client privilege between the police and the prosecutor. The privileged communications in question related to a conversation "between provincial Crown counsel who was engaged in the prosecution"7" and the investigating police officer. In holding that there could be no solicitor client privilege in that context, McEachern C.J. stated:

\footnotetext{
I reject the submission that communications about the question of identification between a police officer who is to be a Crown witness and ('rown counsel are protected by solicitor-and-client privilege. Such an extension of solicitor-and-client privilege in the criminal context is unsupported by authority and could result in witnesses being able to withhold evidence which may be necessary ir justice is to be done ... the suggestion that a solicitor-and-client relationship exists between a police officer and (rown counsel is untenable. ${ }^{80}$
}

The practical extension of solicitor client privilege to potential witnesses is certainly problematic and carries with it the bizarre ability referred to in the above passage. This rationale is the main basis against a finding of privilege and is actually one of the most compelling arguments in the jurisprudence.

The Girouard case has the misfortune of being the most improperly cited case in the jurisprudence. It has been used to support a range of positions in other cases from the proposition that a privilege relationship could never exist between the police and the Crown to the assertion that solicitor client privilege does in fact exist between the police and the Crown. In actuality, Girouard is a well-reasoned, coherent statement on this issue. The Crown in Girouard was a prosecutor who was talking with a police witness outside the court and it was that conversation which the privilege was sought to protect. The Crown was clearly a prosecutor, not an advisor. Had the Chief Justice used more precise language in describing the Crown, a more coherent principle might have been created.

It is true that the premise of a privileged relationship between a Crown who is prosecuting and a police officer who is a witness is not supported in law. However, within the traditional definition of solicitor client privilege, a Crown who is not a prosecutor but merely an advisor would surely be considered a solicitor for the purposes of privilege. If they are neither a prosecutor nor a solicitor then what could they be? Although it was never formally articulated, the principle from Girouard is that no privilege could exist between a Crown who is prosecuting a matter and a witness in that matter. But that very limited situation represents the extent of applicability of the reasoning from Girouard. For the purposes of providing consistency in the jurisprudence on the issue of whether a privilege relationship could exist 
between the police and a Crown who is an advisor, Girouard's reasoning is extremely helpful.

In Gray I, the issue of privileged communications concerned opinions received from Department of Justice lawyers in relation to the lawfulness of conducting a "reverse sting," whereby the police pose as drug vendors as opposed to drug buyers. Although this decision was appealed, the appeal was not in relation to the solicitor client issue, but instead in regards to Canada Evidence Act provisions which relate to public interest immunity. ${ }^{81}$ Justice Oppal reviewed several of the previous authorities on this issue, such as Medicine Hat ${ }^{82}$ and Girouard. After noting that it was impossible to reconcile the jurisprudence, he adopted the reasoning from Girouard that found that no such privilege existed: "I find [McEachern C.J.'s] reasoning both appealing and compellable because of the concern that he expressed about a witness being able to withhold necessary evidence. Furthermore, there is no authority for the proposition that a police officer is a "client as such." ${ }^{83}$ Had the reasons in Gray $I$ stopped there, this case would have been at the least consistent with the idea that no privilege exists between the police and a Crown who is prosecuting. Unfortunately, the subsequent analysis renders any principle from Gray $l$ meaningless.

The first problem is that, after adopting the reasoning from Girouard, which appears to espouse a general principle, Oppal J. then stated, "[i]t is not necessary in this application to decide the larger issue of whether all conversations between Crown counsel and police are clothed with solicitor-client privilege. ${ }^{184}$ Having first adopted the general principle that no privilege could exist between the police and the Crown, Oppal J. retreated from supporting that principle. To further add to this confusion, he then proceeded to waive the very privilege that he most recently decided did not exist: "the Crown's right to solicitor-client privilege is removed." ${ }^{85}$ It is also worth noting that the right to the privilege is the client's right, not that of the solicitor. The Gray 1 reasoning, therefore, is difficult to follow and is not helpful in understanding the jurisprudence surrounding this issue.

Even though the Crown in Gray I was clearly not the prosecutor, as the communications in question related to opinions on the lawfulness of a reverse sting, the Court incorrectly adopted the reasoning from Girouard. ${ }^{86}$ By failing to delineate the Crown as an advisor versus the Crown as prosecutor, the basis for the finding that no privilege existed is dubious. Although the reasoning from Gray $l$ does not help support the principle that there is a privileged relationship between the police and an advisor Crown, it is not because of the ultimate finding of no privilege. Rather, it is due to the flawed application of the case law and contradictory analysis.

In Regan [Application], ${ }^{87}$ the issue surrounding privileged communications concerned legal advice that was provided by the Crown prosecutor to the police during the course of an 
investigation. Although there is little factual analysis of the situation surrounding the communications, Judge Batiot conducted a comprehensive review of the relevant jurisprudence. He reviewed the Wigmore criteria and Gray 1 and then distinguished Sander as merely assuming the existence of privilege ${ }^{88}$ and found that Medicine Hat was not relevant, since the communications there were merely statements of fact. ${ }^{89}$ The Judge then acknowledged Girouard as a case that specifically related to the Crown as prosecutor and forbid a finding of such a privileged relationship. He then summarized the jurisprudence: "There is no authority for the proposition advanced by the Crown here. If there is a privilege it is not one recognized at common law. At most, all we can say is that in the past, some Courts have assumed a solicitor-client relationship existed between a Crown prosecutor and an investigator." 90 In concluding, Batiot J. stated that "[ $[$ ] he law does not recognize a solicitor-client privilege between the police and a Crown Prosecutor. Such police privilege would be incompatible with the prosecutor's duty of fairness and openness, as a 'minister of justice." ${ }^{\prime 91}$ The reasoning used in this case is coherent and provides a logical framework to support the position that no such privilege exists between the police and the prosecuting Crown.

In this case, whether the Crown was a prosecutor or an advisor is not clear from the facts. In noting that the issue of privilege would be context-dependent, given that the Nova Scotia Public Prosecutions $A c t^{92}$ stipulated that one of the duties of the Crown was to provide legal advice to the police, Judge Batiot observed "that determinant of the issue will be the status in law of the prosecutor." ${ }^{.93}$ Although not formally articulated, the principle emerging from the analysis in Regan [Application] is that an inquiry into the role of the Crown, either as a prosecutor or advisor, will be determinative of whether or not a privileged relationship could exist.

The final observation from the Regan [Application] case provides further support for noting the distinction between the Crown as prosecutor and the Crown as advisor. Although Batiot J.'s reasoning would appear to have difficulty in upholding privilege between the police and any Crown, whether prosecutor or advisor, he indicated: "[ $t$ ]he police is not without protection. They can consult with their own solicitor, or one in another government department, such as the Solicitor-General's. In accordance with the jurisprudence already cited, a privilege will attach to the legal opinion received. It will not restrict the prosecutor's discretion. ${ }^{.94}$ The specific reference to restricting the prosecutor's discretion taken in the context of the Regan case, in which the main issue was the apparent collusive relationship between the police and the prosecutor, demonstrates the Court's concern for that specific relationship. Although not specifically enunciated, Regan [Application] is consistent with the traditional rule and does provide further support for its use in the police context. 
In $R . v$. Nesbeth, the issue of solicitor client privilege between the police and various different Crowns was raised in two capacities. ${ }^{95}$ The first concerned the legal opinions between a Canada Customs and Revenue Inspector and a Crown in the Crown Office. The second was raised in relation to communications between a police investigator and the " head Crown' in the Federal Crown offices in Brampton."96 Justice Zelinski of the Ontario Court of Justice failed to find a privileged relationship and in the alternative deemed that it would have had to yield to full answer and defence.

The basis for the Zelinski J.'s finding in Nesbeth was essentially an adoption of the reasons from Girouard that were used for finding that no such privilege could exist. Justice Zelinski borrowed the rejection of the position "that communications about the question of identification between a police officer who is to be a Crown witness and Crown counsel are protected by solicitor-and-client privilege." ${ }^{97}$ When the Crown attempted to base the privilege on an argument that the police are agents of the Attorney-General, Zelinksi J. further rejected the notion of characterizing "any police officer [as] an agent of the Attorney-General." He went on to add that "[i]n any event, the suggestion that a solicitor-and-client relationship exists between a police officer and Crown counsel is untenable." ${ }^{\prime 8}$ There is very little independent analysis done by Zelinski J. in Nesbeth and the reasons provided offer nothing further to the jurisprudence surrounding this issue.

The reasoning used in Nesbeth to hold that no privilege existed between the Crown and the police is suspect. First, Zelinski J. failed to address the general principle enunciated from Medicine Hat, which found that a privileged communication could be sustained in the inhouse, internal context. Second, Zelinski J. improperly adopted the reasoning from Girouard and failed to delineate the role of the Crown in Girouard as the party who was prosecuting the matter. On the facts outlined in Nesbeth, it is clear that the opinions in question came from Crown counsel, who were not only not prosecuting the case, but at the very least were at arms length from the prosecution. By failing to acknowledge the fundamental difference in the role of the Crown, the rationale for finding that no solicitor client privilege existed between the Crown and police becomes vague and likely incorrect.

Before leaving Nesbeth, it is important to highlight another improper basis for finding that no privilege could exist. In providing a further basis for his finding, Zelinski J. stated that "it stretches credulity that police officers, simply by virtue of their membership in a police force ... are acting as agents of the Attorney General/Department of Justice to engage Crown attorneys in a solicitor and client relationship." 99 There is no agency requirement to be met in order to claim solicitor client privilege. An agency situation could provide the basis for a claim of privilege in the proper context, but agency is not a prerequisite for a general finding of solicitor client privilege. Unfortunately, the decision in Nesbeth improperly used the authorities in a selective manner when coming to the conclusion that no privilege could exist between the police and an advising Crown. 
The final case in this category is that of DeRose, which concerned communications between a Crown prosecutor, who was prosecuting the matter, and an auditor with Revenue Canada. ${ }^{100}$ Judge Allen entered into a review of the basis for solicitor client privilege and the special status of the Crown in the administration of justice. He continued with a review of the jurisprudence that supported a finding of no privilege and indicated that "[the] precedents: Re Girouard, supra; R. v. Gray, supra; R. v. Nesbeth, supra, must be put into proper perspective because of the comprehensive review by the Supreme Court in $R$. v. Shirose." With a thorough analysis, Judge Allen found there to be no privilege between the police and Crown in this case.

In explaining his rationale and how the jurisprudence applied in this case, Judge Allen's reasoning is coherent and well-presented. He held that

\begin{abstract}
it would be unworkable on a daily basis if a true solicitor-client relationship were normally created between the prosecution and its witnesses. If this were the case then the prosecutor would be compelled to consult the individual witness before disclosing relevant evidence. Thus, in most circumstances a true solicitor-client relationship is not created between the prosecutor and his or her witnesses. In reality, the true client of the Crown is not an individual but Justice itself. That is not to say that a relationship of this nature could not be created between the prosecution and some of its witnesses. The creation of such a relationship is dependent upon the subject matter of the advice, and the circumstances in which it is sought and rendered: $R$. v. Shirose, supra. Where such a relationship has been created, the privilege is that of the elient and not that of the solicitor. Thus it would be necessary that the actual witnesses, who have become clients, claim the privilege. ${ }^{112}$
\end{abstract}

Although solicitor client privilege was found not to exist in this case, the reference to $R$. $v$. Shirose ${ }^{103}$ suggests that there could be circumstances where the privilege could be found. The benefit of the reasoning from Shirose/Camphell certainly assisted in providing clarity to the decision; however, the real principle driving this decision in never articulated.

By noting the special status of prosecutors and their inability to be considered solicitors for the purposes of the rule, this description of the principle in a negative context, although helpful, is still not clear. This case comes the closest to being able to extract a coherent principle, but frames the idea in a negative context. Had Allen J. chosen to conduct his analysis in a positive manner, the reasoning would have articulated that a Crown who is not prosecuting the matter in question can be considered a solicitor for the purposes of solicitor client privilege.

The body of jurisprudence that is covered in the four categories of cases is not easily reconciled and it remains difficult to extract a coherent principle on solicitor client privilege between the police and the Crown. The analogous situations are merely instructive in understanding general concepts surrounding privilege and are less compelling, as they are not specific to the police/Crown situation. Cases that uphold the privilege and do not waive it are devoid of any substantial reasoning and fail to address the contradictory jurisprudence.

Siupra note 4.

lhid. at para. 52.

lhid. at para. 9()

|1999| I S.C.R. 565 (sub nom. R. v. ('amphell, supra note 3). 
Cases that hold that the privilege does exist, either through assumption or a marginal analysis, and which then immediately revoke it, do more to confuse the situation by practically bypassing the establishment of privilege and instead proceeding directly to the exceptions. Cases that find that no such privilege exists, although based on better reasoning, contain confusing references to the other cases and fail to actually articulate any general principle. To this must be added the governing legislation that is either contradictory or silent on this point and the jurisprudence that also remains unclear.

Notwithstanding these shortcomings, a more critical review does demonstrate that provided the Crown is not acting as a prosecutor, Crown counsel can provide a legal opinion that would be protected by the solicitor client privilege rulc. Aside from a few exceptions, and upon closer inspection, the reasoning used in all of the cases is quite consistent. This accidental consistency is often buried beneath improperly cited cases and a failure to properly apply the methodology of the traditional solicitor client rule. The jurisprudence can be resolved to a common principle, but what is still required is a decision that correctly articulates the solicitor client privilege rule in the police/Crown context. ${ }^{104}$

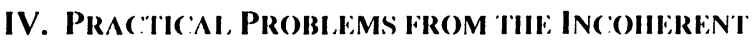 ApPIIC:ATION OFF THL: RIIA:}

With the case law and the legislation providing a confusing basis for the application of the solicitor client rule in the police/Crown context, the actual problems created for the police and the Crown only serve to highlight the need for a more coherent principle. The inability of the police to understand how they can obtain and protect a legal opinion is extremely problematic for their investigations. Also, Crown attorneys face continual challenges to their impartiality by way of abuse of process motions and subpoenas.

\section{A. Promi.lims For Til: Pol.i(:E}

The primary problem for the police is that there appears to be no coherent basis upon which they can determine when and if a legal opinion will be protected. The case law on this topic is without clear direction on just how a privileged legal opinion can be obtained. As police investigations are becoming more complex, the need for legal advice on matters that arise in those investigations is a necessity, as "many peace officers who swear Informations

In.1 By comparison to the situation in the (Jnited States, it would seem that the concern over the proximity of the relationship between investigating agency and the district attorney, or U.S. altorney, does not exist. As district attorneys are routincly involved in many areats of the investigation, and in lact are often considered enforement oflicers themselves, the issues experienced in (anadian jurisprudence do not materialize in the Inited States. leor an example of the extent of the roles that a district altorney can take in an investigation, see Paula J. (ascy, "Regulating Federal Proseculors: Why Mel)ade Should Be Repealed" (20)2) 19 (ia. St. II. I. Rev. 395. Also, the wealth of American commentary on the isste primarily relates to the role of government legal advisors and is concerned with the role of government counsel in an intergovernmental sense. These discussions do not specifically relate to the unique circumstance of prosecutors providing legal opinions to law enforcement agencies. Sec lonry $\wedge$. Barsdate. "Altorncy-( lient Privilege for the (iovernment I:ntity" (1988) 97 Yale I..J. 1725: I'atricial I:

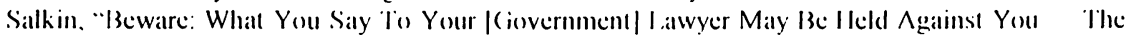

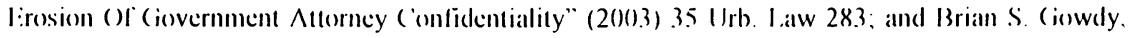

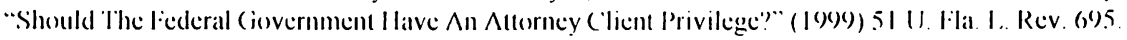


are provided with neither the training nor the legal assistance to ensure that the Information will be adequate without revision." 105 The drafting of Informations is but one example of the more legally complex environment in which the police are working. Several of the cases referred to in Part III were specifically related to the police obtaining advice from the Crown in relation to "reverse stings." With these cutting-edge techniques being used more frequently, the problem of not being able to protect advice from the Crown will remain.

The practical difficulty from this situation is that the police, knowing that there is a possibility that anything said to the Crown might not be protected, will not be as forthcoming in their discussion with the Crown. This reluctance for candour, along with the public's interest in the police's ability to conduct investigations, education of the criminal element, and a refusal by other domestic or foreign police agencies to share information for fear of disclosure are all practical examples of the problems created by the failure to protect legal opinions. ${ }^{106}$

In fact, the potential for this to occur has been recognized by the Supreme Court of Canada: "It is of great importance, therefore, that the RCMP be able to obtain professional legal advice in connection with criminal investigations without the chilling effect of potential disclosure of their confidences in subsequent proceedings." 107 The concept of a "chilling effect" is often described in the freedom of expression context as one that would "chill legitimate expression." 108 The chilling concern for the court relates to the potential for the police, who are aware that no privilege may in fact exist, to withhold pertinent details from the Crown. This concern does not relate to the legitimate, substantive disclosure routinely provided by the police, but concerns investigative strategies and investigation techniques. Any withholding must be seen as a step backwards in our modern criminal law system where the police's conduct must be transparent.

The police cannot be the only entity involved in the judicial system without the benefit of protected legal advice. Given that the police play a major role in the administration of justice, their need for protected advice is essential. Furthermore, the police must know exactly how to engage the process to protect such advice. With the body of jurisprudence as it presently stands, the practical problems for the police will continue until a coherent principle is established that explains how the rule of solicitor client privilege operates between the police and the Crown.

\section{B. Problems for the Crown}

Perhaps the most problematic area of the solicitor client privilege rule as it applies to the police/Crown context are the difficulties created for the Crown. Because of the Crown's dual roles of independent officer of the court and quasi-legal advisor to the police, the Crown, too, is left exposed to difficulties. For the Crown, the main problems involve abuse of process motions and becoming witnesses in a matter that they are prosecuting. By understanding the 
possibility for these events to occur, the Crown may be unwilling to provide advice to the police for fear of being subpoenaed.

To demonstrate the extreme end of the spectrum of the abuse of process instances, one need only examine Dix v. Canada (A.G.). ${ }^{109}$ There, an allegation of abuse of process concerned the relationship between the Crown prosecutor and the police during the investigation. The Crown had entered into evidence a letter written by an inmate who was incarcerated with the accused in this case. However, the letter was in fact authored by the police and the Crown's use of this letter, without divulging its origins, was held to be misleading. The alleged involvement of the Crown led the presiding judge to remove the Crown, as the prosecutor "had become a witness regarding this issue and could not be both witness and prosecutor." 110

The Judge characterized the role of the Crown as "over the legal, functional, and ethical division which should exist between the respective functions of the police and prosecutors and that his involvement was greater than it needed to be and greater than it was desirable to be." Ulitimately, the Crown prosecutor was held personally liable for the punitive damages awarded to the accused in the amount of $\$ 200,000 .^{112}$ Although Dix may be an anomaly in abuse of process situations, it certainly highlights the potential difficulties of a close working relationship between the Crown and the police.

More common is the possibility that this close relation with the police, which is often the basis for abuse of process motions, will lead to attempts to have the Crown prosecutor subpoenaed as a witness, thereby removing them from prosecuting the trial. In $R$. v. Regan, ${ }^{113}$ the abuse of process motion was based on a close working relationship between the Crown and the police as well as on allegations of "judge shopping." Ultimately, the defence attempted to subpoena the Crown who at that stage of the proceeding had left the prosecution. ${ }^{114}$ In $R$. v. Innocente, ${ }^{115}$ the basis for the abuse of process motion was an alleged collusive relationship between the Crown attorney and the police during the investigation and in earlier court proceedings. Although the abuse of process motion was overturned at the Court of Appeal, ${ }^{16}$ it still provided a basis upon which the defence unsuccessfully attempted to subpoena the Crown. The ability to remove a prosecutor from a case by subpoena still remains a problem for Crowns due to the proximity of their relationship with the police.

The lack of a coherent principle surrounding the application of the solicitor client privilege rule in the police/Crown context is a significant factor in bringing both abuse of process motions and subpoenas for prosecutors. Although few of these motions succeed, the fact that they exist supports the premise that the nature of the relationship between the Crown and the police is dubious. As noted by Phillip Stenning, "[that] the precise legal relationship between

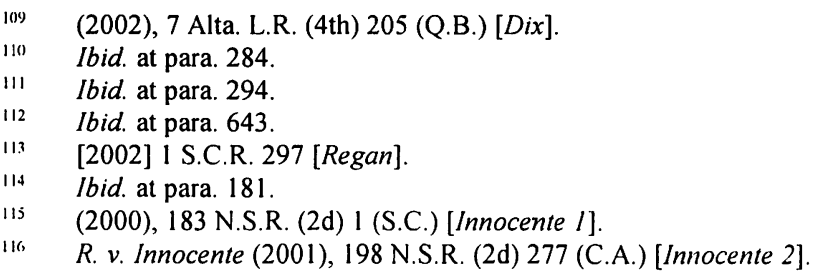


the police and public prosecutions authorities is so unclear in Canada may be regarded as undesirable, because of its implications for the accountability of prosecutorial authority." 117 The concern of Crown prosecutors is real and their problems with the inconsistent application of the solicitor client privilege rule have been critiqued because Crown prosecutors "unlike any other solicitors or counsel, become compellable witnesses in every significant criminal trial and will be required to disclose the advise they gave." IIx This may overstate the problem for the Crown, but the fact remains that because of the state of the law, the impartiality of Crown prosecutors is routinely challenged.

The problems created by the lack of a coherent principle surrounding solicitor client privilege in the police/Crown context impact both the police and the Crown. There appears to be little consistency in the application of the rule. By failing to understand the reasoning used in making a determination of the privilege, the Crown is routincly exposed to risk and the police are frequently without the benefit of privileged legal advice. The first step in solving the practical problems for the police, the Crown, and the rule itself is to reconcile the jurisprudence surrounding this issue into a coherent principle. By reconciling the case law and legislation to such a principle, the result will be a better understanding of the rule that will allow for the police and the Crown to solve many of their practical problems with the present situation. "1"

\section{CONCIIISION: TIIF OPTIMIM MODHI, FOR THE POIICE IS INIDEPENDENT, IN-HOUSE COUNSLI.}

The importance of extracting a coherent principle from the jurisprudence surrounding solicitor client privilege in the police/Crown context goes beyond attempting to understand the various decisions. Its importance relates to solving the actual problems created by the apparently inconsistent and confusing decisions on this issuc. With no ability to understand in what circumstances the privilege can be engaged or lost, the police and the Crown are plagued with the kind of problems discussed in Part IV of this article. Ilowever, with the identification of the "accidental consistency," a model can be employed by the police that not only resolves the practical problems, but provides an optimal situation for maintaining the integrity of the administration of justice.

By identifying the principle of a solicitor client relationship between the police and a Crown advisor, the police, the Crown, and the rule itself will be better served. However, there is still a concern about the proximity of such a relationship between the police and Crown.

\footnotetext{
117 Phillip ('. Stenning, Appearing for The ('rown (()ucbec: Brown l cegal P'ublications, 1986) at 280. (iray, supra note 52 at 33.5 .

11" The ability to explore the issuc of the inherent conflict of interest of the ('rown as advisor to the police and independent officer of the court is beyond the seope of this article. It is worth noting that certain consideration must be given to the Supreme (ourt of ('anada's decision in R. v. Stincheombe, |1991] 3 S.C.R. 326 |Stinchoombe|, which espoused the mandatory recpuirement that complete disclosure of the entire police investigation is recuired. ()f course, included in that would be opinions or advice provided to investigators by the ('rown. 'The corresponding repuirement of solicitor client privilege is in direct conflict with the principles of Stincheombe. What is required is an in-depth analysis into the underlying principles that support the basis for the enflicting positions. However, lhere is some indication from the courts that any protection for privileged communications would ultimatcly yicld lo the requirements of full disclosure (sece e.g. Sander, suprea note 56 ).
} 
The concern relates to the need for maintaining impartiality in the administration of justice. The Marshall Inquiry acknowledged the importance of a divide between the Crown and law enforcement:

We recognime that cooperative and effective consultation between the police and the ('rown is also essential to the proper administration ol justice. But under our system, the policing linnction - - ihat of investigation and law enforement -- is distince from the prosecuting function. We belicve the maintenane of a distince line between these two functions is essential to the proper administration of justice. ${ }^{120}$

Although the "accidental consistency" suggests that a privileged relationship can exist between the police and a Crown advisor, it would not represent the ideal situation as per the Marshall Inquiry. What would satisfy the concern of the Marshall Inquiry would be the police use of in-house counsel, as opposed to a Crown advisor, to obtain legal advice.

For the police, the benefits would relate to legal opinions that not only reflect their special status in the administration of justice, but also their independence from all other entities involved. Most importantly, the police would have certainty in knowing that an opinion from their in-house counsel constitutes a privileged communication and would be protected as such. That situation would be in full compliance with both the traditional rule and the jurisprudence. Provided that the core elements of the traditional rulc are met, there would be no confusion as to the status of the solicitor. This is not to say that the courts could not revoke the privilege pursuant to the recognized exceptions, but the police will now have a more reliable source for privileged legal opinions.

By utilizing in-house counsel for legal opinions as opposed to a Crown advisor, the independence of such opinions could not be questioned. Although some police agencies, such as the RCMP's Integrated Proceeds of Crime Units, use contracted Department of Justice lawyers as in-house counsel for legal opinions, the independence of such situations must be considered. The fact remains that a Department of Justice lawyer acting as in-house counsel to a police unit is still part of the Attorney General's oflice. Aside from questioning just how impartial they could be, the Department of Justice in-house counsel model still does not satisfy the concerns expressed in The Marshall Incuiry. Only by maintaining a strict separation between the police and the Crown can independence be achieved. The independent, in-house counsel model can deliver this.

For the Crown, the benefits to be gained would be a reduction in the challenges to their impartiality and the problems which result from such challenges. By maintaining a strict division between their office and the police, abuse of process motions that are based in allegations of collusion would be eliminated. By maintaining no advisory capacity with respect to the police, the structure that has historically provided for abuse of process motions is removed. Subsequently, there will be a reduction in subpoena motions for Crown counsel. By not providing any opinions, Crown counsel would not be exposed to removal from a case. The use of independent, in-house counsel by the police would go a long way toward helping the Crown maintain its quasi-judicial role in the administration of justice. 
The police's use of independent, in-house counsel will provide much needed clarity in the jurisprudence surrounding the application of the traditional solicitor client privilege rule in the police context. Rather than forcing the courts into a confusing analysis of the existence of the privilege, which the jurisprudence demonstrates, the focus will be on the exceptions to the rule. By creating a coherent structure, such an approach will ensure that this substantive rule of law remains intact. Most importantly, it will allow the courts to spare the integrity of this rule when the issues of solicitor client privilege and disclosure come into direct conflict. By resolving these issues at the exceptions stage, the requirements for a privileged relationship will be congruent in both the traditional model and in the police/Crown context.

The jurisprudence surrounding the issue of solicitor client privilege in the police/Crown context appears confusing, but in actuality is consistent. This "accidental consistency," although never articulated, does provide a model that not only reconciles the confusion in the jurisprudence, but also establishes the framework for creating an optimal situation. The use of in-house counsel by the police would solve the historical difficulties experienced by the courts when addressing this issue and would also assist the Crown in their requirement to remain impartial. It would allow the police a privilege that every other person in this country is afforded and, overall, the police's use of independent, in-house counsel would go far in supporting the integrity of the administration of justice in this country. 